\title{
Entrepreneurship and "Clusterization Process" in the Tourism and Agriculture Sector
}

\author{
Ilan Bijaoui ${ }^{1, *}$, David Regev² \\ ${ }^{1}$ The Graduate School of Business Administration, Bar-Ilan University, Israel \\ ${ }^{2}$ International Business and Innovation Institute, Israel
}

Copyright $(2016$ by authors, all rights reserved. Authors agree that this article remains permanently open access under the terms of the Creative Commons Attribution License 4.0 International License

\begin{abstract}
Our research is focused on two main and related issues: evaluate whether the required entrepreneurial capabilities are present in the region, and how the open incubator model, a hybrid model between the Incubator and Industrial District models, must proceed in order to generate a "clusterization process." The three of the McClelland entrepreneurial levels are ready to invest in their own businesses and to cooperate with other businesses. The need for power level is even ready to seek external sources of financing. Connectors are strongly entrepreneurial, ready to take risks, and to follow new trends in business. Mavens are not ready to share their business knowhow with other businesses within the framework of a common organization. Salesmen belong to the family care entrepreneurial level and are ready to take risks in order to improve entrepreneurship in family businesses.
\end{abstract}

Keywords Entrepreneurship, Cluster, Value Chain, Networking, Rural Development, Open Incubator, Tipping Point

\section{Introduction}

Entrepreneurship in rural areas is a challenge in many developed countries. Because farms require increasing means of production (land, machinery, irrigation, etc.) in order to compete, the agricultural workforce is leaving the agricultural production cycle, which necessitates the development of business initiatives in other areas. The rural population of the European Union decreased by $0.8 \%$ between 2010 and 2011, compared with a 5.8\% growth in the urban population (Eurostat, 2012). To keep the balance between village and town, the EU initiated a program called Leader + , which aims to help develop projects that provide employment in rural areas. In a recent document, the European Commission indicated that despite various programs that encourage employment in the rural areas, these areas represent only $17 \%$ of all areas of employment growth in the last decade $(2012, \mathrm{EU})$.

The percentage of the rural population in Israel is changing slowly. In 1995, about 510,000 people lived in rural areas compared with about 640,000 in 2010, an increase of $25 \%$. By contrast, the urban population grew from 5.1 to 7.0 million, an increase of about $37 \%$. In the south of the country the situation is worse. Between 2009 and 2010, 72,000 people left the region, compared with 68,000 people who arrived (CBS, 2011), a net loss of 4,000 people.

\section{Study Objective}

The objective of the study is to determine whether the existing entrepreneurial level is able to generate the development of clusters using open incubator model in two main rural sectors of this region, agriculture and tourism, and under which conditions.

\section{Entrepreneurial Thinking}

According to Schwab (2011), entrepreneurship is the innovative fuel that generates employment and economic growth. To promote entrepreneurship, it is necessary to combine economic, social, and cultural activities (Hart, 2003). Wennekers, Uhlaner, and Thurik (2002) and Peña et al. (2010) distinguished between activity at the level of the entrepreneur (supply side) and that of the business environment (demand side). At the level of entrepreneur, they refer to the ability to establish and develop businesses and examine the entrepreneurs' priorities, education and training, skills, and knowledge. At the business environment level, they refer to environmental conditions that create opportunities for entrepreneurship, such as culture, taxation, R\&D, capital, health, economic development, immigration, science and technology, and aid organizations. 
The connection between the entrepreneur and business environment levels requires the implementation of a model that supports and encourages appropriate networking between entrepreneurs, and a supportive and nurturing business environment. First, we examine the studies that deal with the profile of the entrepreneur (supply side) and discuss ways to promote entrepreneurship that generates economic development. Next, we consider the business environment (demand side) and the models implemented to promote economic development based on the promotion of entrepreneurship.

The literature on entrepreneurs focuses on aspects of their cognitive perceptual ability and the degree of risk they are willing to take (Pena et al., 2010). Craid (1992) referred to communication skills, analytical skills, knowledge, and the ambition of the entrepreneur. Kurilsky (2000) stressed the entrepreneurial spirit that directs the entrepreneurship. Shane and Venkataraman (2000) emphasized the importance of the combination of identifying an opportunity and realizing it as a major factor in the success of entrepreneurship. According to Wennekers and Thurik (1999), entrepreneurial ability becomes stronger with increasing intensity of activity, level of innovation, willingness to take risks, competitive aggressiveness, and desire for independence. The greater this capability, the better the business results (Keh et al., 2007; Stam \& Elfring, 2008; Wiklund \& Shepherd, 2005) and the stronger the business growth (Moreno \& Casillas, 2008) are.

McClelland $(1961,1977)$ focused on the motivational potency of distinct levels of self- and social actualization. $\mathrm{He}$ calls the first level of motivation beyond necessity the "need for achievement." This level requires personal responsibility, calculated risks, performance feedback, and task accomplishment.

The second level of motivation is defined as "need for affiliation," requiring the "approval" of the community and conformity with its "wishes and norms." The third level of motivation is characterized by the "need for power" to exercise control and maintain leader-follower relationships. Bijaoui (2011) showed that some participants in the Songai (Benin) training programs had the capability to achieve the first and the second level and a few of them the third level.

Gilad and Levine (1986) and Verheul et al. (2010) distinguished between necessity entrepreneurship and business entrepreneurship. They claimed that the former, defined by them as "push theory," affects economic development only slightly, whereas the latter, defined as "pull theory," has a more meaningful effect on economic development.

Bonnet, Nelson, and Le Pape (2011) showed that in the 2007-2011 period $10 \%$ of initiatives accounted for $50 \%$ of new employment (business entrepreneurship). This means that if we want initiatives to have a greater impact on economic development we must identify and encourage entrepreneurs who have a greater ability than others to influence economic development, in other words, entrepreneurs who are business- and not necessity-minded.
Gladwell (2000) argued that socio-economic phenomena can spread like an epidemic if specific entrepreneurial and environmental conditions are fulfilled: those defined by the law of small numbers, stick factor and context.

The law of small numbers is based on three elements: maven entrepreneurs, those in possession of knowledge; connector entrepreneurs, those capable of transferring knowledge; and salesman entrepreneurs, those able to transform knowledge into added value. A small group of mavens and connectors is likely to affect a large number of salesmen and through them create a viral process of economic development.

Giacomin et al. (2011) examined common types of entrepreneurship in 27 countries and found that the share of business opportunity entrepreneurs among new businesses is largest in the Scandinavian countries (Sweden, Norway, Denmark, and Iceland) and in Anglo-Saxon countries (Britain, the U.S., and Ireland), followed by France, Germany, Italy, Belgium, and the Netherlands. Necessity entrepreneurship is more characteristic of European Mediterranean and Eastern European countries.

Entrepreneurship education greatly affects the number of initiatives, in particular the number of business entrepreneurs. Fayolle and Gailly (2009) demonstrated that the introduction of programs for entrepreneurial education to engineering schools increased the rate of business entrepreneurship among students. Research by the Kauffman Center clearly shows that students who completed their entrepreneurship studies are more successful in sales and in the volume of employment they create.

Entrepreneurship education affects entrepreneurship capacity differently for different entrepreneur profiles. The Center for Entrepreneurship at Kingston University studied the effect of the Bright Future training program on the entrepreneurial capacity of trainees (Athayde, 2010). The enrichment program has significantly increased the desire of trainees to become business entrepreneurs: $71.4 \%$ of participants in the training program were convinced that they had the skills to start a business, compared with $42.4 \%$ before the training. For trainees aged 20-30, the training program had a significantly positive effect on creativity and the willingness to take risks. The desire to work in a team, however, was strengthened at the expense of readiness to lead, especially among those aged 31-44. Strengthening of creativity was particularly evident in trainees with education in social sciences and the arts.

\section{Models for Economic Development}

A cluster is defined as a "geographic concentration of competing, complementary, or supporting firms that develop sale-purchase relationships, use the same pool of technologies, and share customers and existing human resources pools." Firms in a cluster develop competitive advantages based on human capital, the knowledge 
generated in the environment, and local and international demand (Porter, 1990, 1998). But in order to generate a cluster, business entrepreneurship and an "ignition process" initiated by private interest or a public organization are needed.

\section{The incubator as the starting point of a cluster}

The Silicon Valley cluster started as a technological incubator established by the University of Stanford in the early 1950s. Creative enterprises such as HP and Intel were established there in 1967 by former Fairchild Semiconductors employees. The area became a point of attraction for small and large companies alike specializing in the same fields, such as Sun and Apple.

The biotechnology cluster in San Diego developed around the university and research institutes: the Salk Institute, Scripps, and the University of California, San Diego. The initiative began in 1965 with the establishment of Torrey Pines Mesa biotech, which operated as an incubator. The development of the area into a cluster began with the entrepreneur Ivor Royston, who in 1978 founded the company Hybritech, to be acquired in 1986 by Elli Lilly (Bennett, 2008). The success of the Silicon Valley and San Diego clusters is credited largely to the creative entrepreneurship of isolated individuals, at the beginning of their way, who persuaded developers and other firms to follow them.

\section{Government policy initiating a cluster}

Cluster development in Europe is the result of government initiatives in cooperation with local authorities (European Union, 2007). Programs such as EXIST and BioRegio in Germany are the result of federal and regional decisions to support the development of specialized clusters (Colovic-Lamotte \& Tayanagi, 2004). The Finnish government supported the networking program "Networking" as a first step, which later developed into specialized clusters in the field of communications in Turku and Oulu. Companies such as Nokia and ABB were part of the same network (TEKES, 2005). Since 2001, the Japanese government has implemented a new policy presented in the Industrial Cluster Plan (METI) and the Intellectual Cluster Plan (MEXT) (Colovic-Lamotte \& Tayanagi, 2004). METI includes 19 projects in local clusters, including those dealing with metal parts for machines and parts for aircraft (Higashi-osaka), manufacturing of original equipment for the environmental industry (Hitachi), as well as clusters related to ceramics and metals. MEXT acted primarily to expand the budget of universities and to improve the infrastructure and human resources for technology transfer and patent strategy.

\section{Networking model toward a "clusterization process"}

Networking between firms help to develop cooperation improving professional or business capabilities of its members. Its efficiency depends mainly on the initiative of the members. Some of those networks are focused on a part of the value chain, research and development, procurement, financing or sales.

In the Lublin area in Poland farmers organized into 110 groups, market together their agricultural produce (fruits and vegetables) to retailers in Poland and the European Union (Walukiewicz, 2003). Also in the Lublin region eight networks were established, with various specializations in the field of agricultural tourism, including a hospitality industry with a flavor of local culture and folklore, and manufacturing products such as local fabric for tourists. The association, Ziemia Lubartowska (The Lubartow Country), combines the roles of a common board and management for the different open incubators.

Maniwa, in the north of Okayama in Japan, is an area $80 \%$ of which is covered by woods. in 1992 a group of 20 people concerned by the aging of the population and the need for renewal of the traditional industry (Anbumozhi, 2007) initiated a network of 34 timber plants, 16 plants for drying wood, and dozens of factories producing furniture. Their goal was to establish ecological industries based on wood-processing waste, manufacturing ethanol for the production of energy, cellulose, and construction materials. About 75 small and medium-size firms now specialize in these fields. The local university collaborates with the University of Tokyo in developing knowledge in the field of energy. The area has become a center specializing in energy and has attracted investment and other entrepreneurs.

In Udine, Italy, the manufacturers of wooden chairs in 11 local councils, consisting of more than 1,200 businesses, organized the Italian Chair District as an efficient network that combines contemporary influences with local culture. The management of the network emphasizes mainly common promotional activities. Most businesses employ fewer than 20 employees. A total of 14,000 workers are employed and 250 exporters operate in network.

A cooperative is an active network managed according to determined objectives and in which the members are business partners and share the added value created by the common activities. A cooperative fulfill the interest of its members and doesn't intend to create cluster of which the objective is the development of a sector or a region.

In 1865 in the U.S. state of Vermont, the first cooperative specializing in the production of cheddar cheese was established. Since then, cheese producers have multiplied in the region. In 1998, the Vermont Cheese Council organized support for cheese manufacturers by the transfer of knowledge from the Vermont Institute for Artisan Cheese and from the local university in training, research, and technical services.

In the southeast of Ohio eight counties organized together and formed the Appalachian Center for Economic Networks (ACENet), for the purpose of developing a "clusterization process" based on processing of agricultural products. From an initial number of about 12 specializations, today they have 
reached 100. The ACENet Development Center includes a kitchen incubator and a farmers' market. It created a common brand and helped develop find new markets. The opening program, Entrepreneurship in Action, funded by the Appalachian Regional Commission, enables expansion of the clusterization process into packaging, tourism, and the arts.

\section{Open incubator as the generator of a cluster}

Regular incubators create a temporary framework for new small businesses and support a limited number (several dozen) of them. The businesses belong to different business areas, and there is no basis for cooperation between them. At the end of the process, which lasts one or two years, every business must cope with the business environment outside the incubator. It took several years for Stanford incubator and for the San Diego Institute for Research and Development of Torrey Pines Mesa to generate a cluster.

The open incubator (Bijaoui \& Tarba, 2012) handles existing and new businesses that belong to the same business area, located in their natural setting. It guides and supports the individual business as a regular incubator would, and it supports the business sector as an Industrial District along the entire value chain of the business sector and creates an active network of which the objective is to achieve a "clusterization process". The structure of the open incubator is as follows:

\section{BOARD}
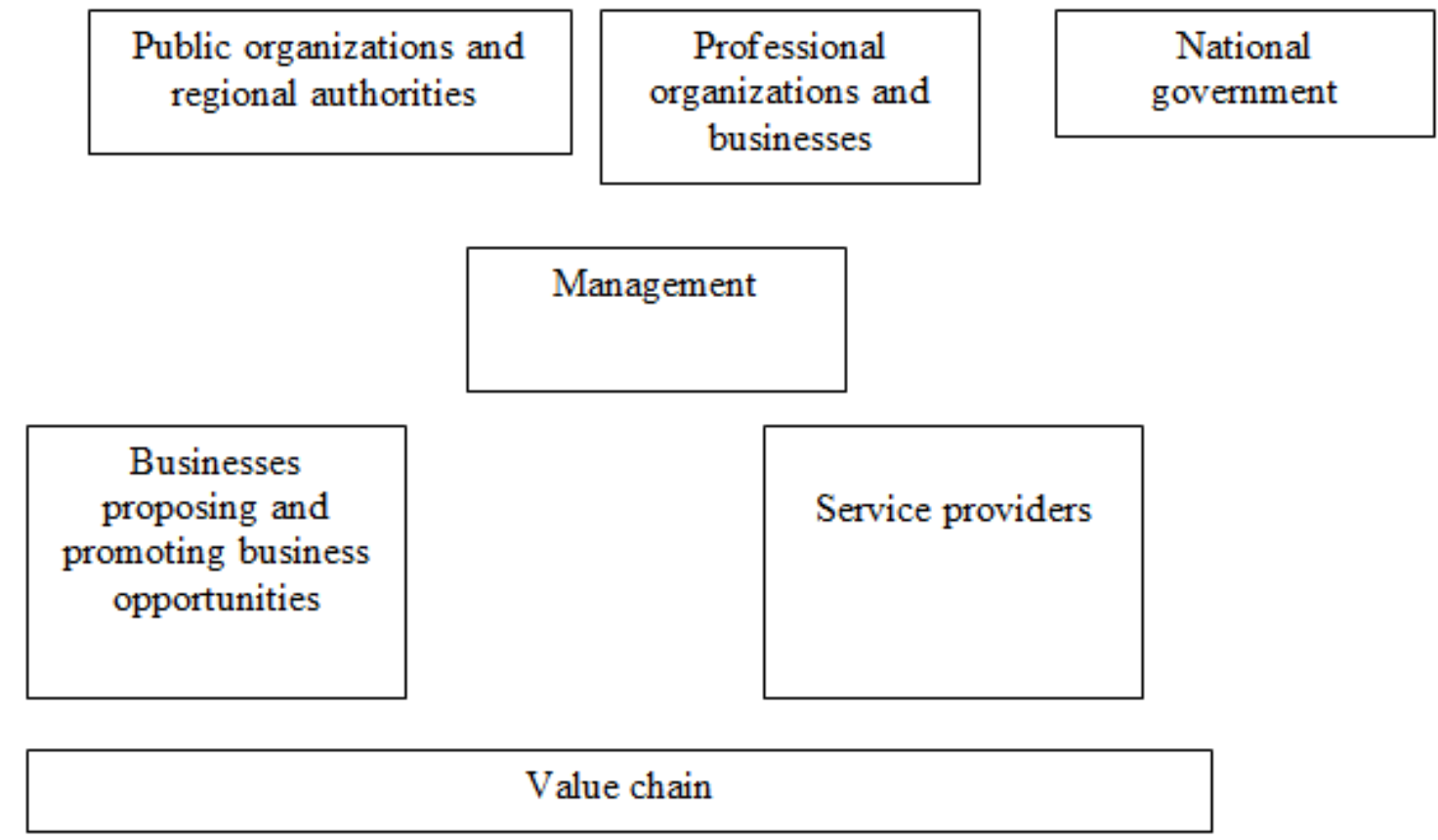

Figure 1. Structure of the Open Incubator

The Board represents the interests of the region and of the selected business sector. Management establishes an active networking between the businesses belonging to the same value chain and by initiating, proposing and promoting common business activities: common supply, common bargaining in supply and sales, common financing, promotion of shared business projects.

Ketels (2004) specified the following conditions for the success of a "clusterization process:"

Taking advantage of proximity for cooperation

Linkages between the firms' activities to advance common goals

Active interaction between firms in the cluster

Critical mass of firms required to accomplish significant achievement 


\section{Entrepreneurship and Open Incubator in the rural area of the Western Negev}

\section{Entrepreneurial level and feasibility of the open incubator in tourism and agriculture}

Our research is focused on two main and related issues: whether the required entrepreneurial capabilities are present in the region, and how the open incubator must proceed in order to generate a "clusterization process."

The sample

In the agriculture sector we have identified approximately 500 growers in the Western Negev. Of these, we have selected randomly 53, 13 of which specialize in field crops and 40 in vegetables. In tourism we have selected a sample of 62 businesses, representing 35\% of the business population in various specializations: guest houses, agro-tourism, attractions, restaurants, and catering. The total sample contains 113 businesses.

Table 1. The Sample

\begin{tabular}{|c|c|c|c|}
\hline Agriculture & Sample & $\begin{array}{c}\text { Estimated } \\
\text { Population }\end{array}$ & $\%$ \\
\hline Field Crops & 13 & 40 & 33 \\
\hline Vegetables & 40 & 460 & 8 \\
\hline Total & 53 & 500 & 10 \\
\hline Tourism & Sample & $\begin{array}{c}\text { Estimated } \\
\text { Population }\end{array}$ & $\%$ \\
\hline Guest house & 23 & 44 & $\mathbf{5 2}$ \\
\hline Agro-tourism & 8 & 23 & $\mathbf{3 5}$ \\
\hline Attractions & 17 & 64 & 27 \\
\hline Other & 12 & 60 & 20 \\
\hline Total & 60 & 176 & 31 \\
\hline
\end{tabular}

The questionnaire

To evaluate the level of entrepreneurship required for the clusterization process initiated by the open incubator, we used McClelland's and Gladwell's classifications as dependent variables, and entrepreneurial attitude as an independent variable.

The questionnaire includes the following variables and parameters.

\section{Dependent variables}

- Parameters classifying the entrepreneur at his relevant level of entrepreneurship according to McClelland:

Family care represents the necessity level. The parameter used was to "meet the needs of his family".

Wider Business represents the first McClelland level, "need for achievement" evaluated by the following parameters: readiness to invest, will to achieve personal and professional objectives.

Appreciated by others represents the "need for affiliation" evaluated by the following parameters: ability to develops, to invest, will to improve his economic situation and his social status.

Lead represents the third highest McClelland level, "need for power" evaluated the parameter: will to be a leader.

- Groups of parameters evaluating the attitude of the entrepreneur according to Gladwell's classification:

Connector: brings people together, has a wide range of contacts, participates in events, consults, likes challenges, is curious, is ready to cooperate, likes to socialize.

Maven: finishes the job, plans, solves, has a different view.

Salesman: is able to convince and is close to customers.

Independent variables

We defined two groups of independent variables:

- Entrepreneurial behavior, parameters: readiness to take risks, plan, cooperate, join forces, solve problems, consult, convince, transfer responsibility, acquire knowledge, understand customer needs, socialize, develop relations, participate in events, innovate, and open new horizons.

- Readiness to invest, parameters: in the current business, in marketing and sales, in training, in management, in export, in new trends, in financing, in the brand, in negotiation, and in a new organization.

Methodology -Data processing technics

Answers for each parameter were recorded on a scale of 1-5, 1 representing the lowest level and 5 the highest.

About the dependent variables, entrepreneurs answering by 4-5 to the parameter "meet the needs of his family" and a lower mark (1-3) to the other parameters referring to the parameters expressing a "need for achievement", "need for affiliation" or "need for power" has been classified as "Family Care" entrepreneurs. In the same way those who answered 4-5 to parameters expressing need for achievement or need for affiliation or need for power were classified in the relevant category respectively.

About the independent variables, the level of "entrepreneurial behavior" and the "readiness to invest" has been evaluated by the total of the marks given to the parameters allowing the evaluation of each independent variable detailed above. As for the dependent variables each parameter received a mark on the scale of 1 to 5 .

All the parameters had an equal weight. We are aware that it could not be the case in reality.

Hypotheses

We checked the following hypotheses:

$\mathrm{H} 1$ : Businesses at the family care entrepreneurial level is 
focused don't seek for new trends in business and don't cooperate with other businesses.

$\mathrm{H} 2$ : Businesses at the business wider (need for achievement) entrepreneurial level are seeking new knowledge and are ready to cooperate with other businesses.

H3: Businesses at the appreciated by others (need for affiliation) entrepreneurial level are seeking new trends in business and are ready to cooperate with other businesses.

H4: Businesses at the lead (need for power) entrepreneurial level are able to convince and are seeking external financing.

H5: Connectors are at the need for affiliation entrepreneurial level and explore new trends in business.

H6: Mavens are at a high entrepreneurial level, possess business knowledge, and are ready to cooperate.

H7: Salesmen belong to the family care entrepreneurial level but are ready to take risks and to become also connectors.

\section{Results and Discussion}

The family care entrepreneurial level displays weak entrepreneurial behavior ( $\mathrm{R}^{2}$ weak, 0.170). Contrary to expectation, entrepreneurs at this level are seeking new trends in business but do not cooperate with other businesses.

H1, was partially rejected.

Table 2. Regression between "Family Care" entrepreneurial level and independent variables

\begin{tabular}{|c|c|c|c|c|c|}
\hline \multicolumn{7}{|c|}{ Coefficients $^{\mathrm{a}}$} \\
\hline \multirow{2}{*}{$\mathrm{R}^{2}=.170$} & Unstandardized Coefficients & Standardized Coefficients & \multirow{2}{*}{$\mathrm{t}$} & \multirow{2}{*}{ Sig. } \\
\cline { 2 - 6 } & $\mathrm{B}$ & Std. Error & Beta & 17.772 & .000 \\
\hline (Constant) & 3.778 & .213 & & 2.369 & .020 \\
\hline Customer support & .114 & .048 & .212 & 3.177 & .002 \\
\hline New trends & .168 & .053 & .286 & -2.384 & .019 \\
\hline Cooperate with other businesses & -.353 & .148 & -.209 & & \\
\hline \multicolumn{7}{|c|}{ Dependent Variable: Family care } & \\
\hline
\end{tabular}

The need for achievement level of entrepreneurship shows a stronger entrepreneurial orientation $\left(\mathrm{R}^{2}=0.223\right)$. Entrepreneurs are ready to cooperate and are interested to invest in training in order to improve their knowledge. They are also developing new trends in business. $\mathrm{H} 2$ was confirmed.

Table 3. Regression between "Wider Business" entrepreneurial level and independent variables

\begin{tabular}{|c|c|c|c|c|c|}
\hline \multicolumn{7}{|c|}{ Coefficients $^{\mathrm{a}}$} \\
\hline \multirow{2}{*}{$\mathrm{R}^{2}=.223$} & Unstandardized Coefficients & $\begin{array}{c}\text { Standardized } \\
\text { Coefficients }\end{array}$ & $\mathrm{t}$ & \multirow{2}{*}{ Sig. } \\
\cline { 2 - 6 } & $\mathrm{B}$ & Std. Error & Beta & 3.511 & .001 \\
\hline (Constant) & 1.617 & .461 & & 2.853 & .005 \\
\hline New trends & .214 & .075 & .251 & 3.009 & .003 \\
\hline Bring people together & .287 & .095 & .264 & 2.746 & .007 \\
\hline Invest in training & .224 & .081 & .230 & & \\
\hline \multicolumn{7}{|c|}{ Dependent Variable: "Wider business " } \\
\hline
\end{tabular}

Entrepreneurs at the appreciated by others (need for affiliation) level are seeking new business trends and are ready to cooperate. They have a similar profile as the need for achievement level, but more emphasized $\left(\mathrm{R}^{2}=.355\right.$ compared to $\mathrm{R}^{2}$ $=.223$ ).

$\mathrm{H} 3$ was confirmed.

Table 4. Regression between "Appreciated by others" entrepreneurial level and independent variables

\begin{tabular}{|c|c|c|c|c|c|}
\hline \multirow{2}{*}{$\mathrm{R}^{2}=.355$} & Unstandardized Coefficients & $\begin{array}{c}\text { Standardized } \\
\text { Coefficients }\end{array}$ & \multirow{2}{*}{$\mathrm{t}$} & \multirow{2}{*}{ Sig. } \\
\cline { 2 - 6 } & $\mathrm{B}$ & Std. Error & Beta & -2.112 & .037 \\
\hline (Constant) & -1.226 & .581 & & 4.234 & .000 \\
\hline Bring people together & .509 & .120 & .339 & 3.899 & .000 \\
\hline New trends & .368 & .094 & .312 & 3.759 & .000 \\
\hline Invest in training & .386 & .103 & .287 & & \\
\hline \multicolumn{7}{|c|}{ Dependent Variable: Appreciated by others } \\
\hline
\end{tabular}


Entrepreneurs at the lead level, representing McClelland's need for power level, are able to convince and are seeking external financing to expand their business. They are also ready to cooperate with other businesses. H4 was confirmed.

Table 5. Regression between "Lead" entrepreneurial level and independent variables

\begin{tabular}{|c|c|c|c|c|c|}
\hline \multirow{2}{*}{$\mathrm{R}^{2}=.347$} & Unstandardized Coefficients & $\begin{array}{c}\text { Standardized } \\
\text { Coefficients }\end{array}$ & \multirow{2}{*}{$\mathrm{t}$} & \multirow{2}{*}{ Sig. } \\
\cline { 2 - 6 } & $\mathrm{B}$ & Std. Error & Beta & & .002 \\
\hline (Constant) & -1.898 & .607 & & -3.126 & .003 \\
\hline New trends & .299 & .097 & .257 & 3.067 & .025 \\
\hline Bring people together & .293 & .130 & .198 & 2.265 & .013 \\
\hline Convince & .350 & .139 & .235 & 2.973 & .004 \\
\hline Financing & .275 & .092 & & \\
\hline
\end{tabular}

Connectors are strongly entrepreneurial $\left(\mathrm{R}^{2}=0.522\right)$, at the level of need for affiliation (appreciated).

They are following new business trends and are ready to take risks. H5 was confirmed.

Table 6. Regression between "Connector" Gladwell's role and independent variables

\begin{tabular}{|c|c|c|c|c|c|}
\hline \multicolumn{6}{|c|}{ Coefficients $^{\mathrm{a}}$} \\
\hline \multirow{2}{*}{$\mathrm{R}^{2}=.522$} & \multicolumn{2}{|c|}{ Unstandardized Coefficients } & $\begin{array}{l}\text { Standardized } \\
\text { Coefficients }\end{array}$ & \multirow{2}{*}{$\mathrm{t}$} & \multirow{2}{*}{ Sig. } \\
\hline & B & Std. Errol & Beta & & \\
\hline (Constant) & 16.375 & 1.314 & & 12.461 & .000 \\
\hline New trends & 1.107 & .303 & .263 & 3.653 & .000 \\
\hline Take risks & 1.430 & .329 & .300 & 4.352 & .000 \\
\hline Appreciated & 1.480 & .263 & .414 & 5.631 & .000 \\
\hline
\end{tabular}

The entrepreneurial orientation of mavens is also strong $\left(\mathrm{R}^{2}=0.374\right)$, at the level of need for affiliation. They possess business knowhow but are not ready to participate in the creation of a new common organization.

H6 was not confirmed.

Table 7. Regression between "Maven" Gladwell's role and independent variables

\begin{tabular}{|c|c|c|c|c|c|}
\hline \multicolumn{7}{|c|}{ Coefficients $^{\mathrm{a}}$} \\
\hline \multirow{2}{*}{$\mathrm{R}^{2}=.374$} & \multicolumn{7}{|c|}{ Unstandardized Coefficients } & $\begin{array}{c}\text { Standardized } \\
\text { Coefficients }\end{array}$ & $\mathrm{t}$ & \multirow{2}{*}{ Sig. } \\
\cline { 2 - 6 } & $\mathrm{B}$ & Std. Error & Beta & 15.651 & .000 \\
\hline (Constant) & 12.554 & .802 & & 2.428 & .017 \\
\hline Appreciated & .296 & .122 & .197 & -3.422 & .001 \\
\hline Create a new organization & -1.588 & .464 & -.260 & 5.321 & .000 \\
\hline Business knowhow & .912 & .171 & .433 & & \\
\hline \multicolumn{7}{|c|}{ Dependent Variable: Maven } \\
\hline
\end{tabular}

Salesmen belong to the family entrepreneurial level but are ready to take risks and to be also connectors. H7 was confirmed.

Table 8. Regression between "Salesman" Gladwell's role and independent variables

\begin{tabular}{|c|c|c|c|c|c|}
\hline \multicolumn{5}{|c|}{ Coefficients $^{\mathrm{a}}$} \\
\hline \multirow{2}{*}{$\mathrm{R}^{2}=.408$} & \multicolumn{2}{|c|}{$\begin{array}{c}\text { Standardized } \\
\text { Coefficients }\end{array}$} & $\mathrm{t}$ & \multirow{2}{*}{ Sig. } \\
\cline { 2 - 6 } & $\mathrm{B}$ & Std. Error & Beta & -.658 & .512 \\
\hline (Constant) & -.698 & 1.060 & & 3.001 & .003 \\
\hline Family & .531 & .177 & .221 & 4.478 & .000 \\
\hline Take risks & .596 & .133 & .373 & 3.579 & .001 \\
\hline Connector & .100 & .028 & .297 & & \\
\hline \multicolumn{7}{|c|}{ Dependent Variable: Salesman } \\
\hline
\end{tabular}




\section{Conclusions}

Entrepreneurs at the family care level are open to raising their entrepreneurial level. The three levels of the McClelland motivation to entrepreneurship have the relevant profile required to improve the added value of their own business and also of other businesses. The need for power motivation level is even ready to take risks.

Connectors, Salesmen and Mavens are strongly entrepreneurial.

Few cooperation exists between entrepreneurs. But they are ready to participate in a common networking in order to improve their professional and business capabilities. They are not ready to initiate and manage it. The open incubator described above can play this role by:

- improving current business activities by better efficiency in cost and sales,

- generating new common business along the value chain of the business sector

- encouraging the mavens to share their knowledge with others and improve the entrepreneurial level of family care businesses;

- supporting connectors and salesmen in their cooperation with family care businesses;

\section{REFERENCES}

[1] Anbumozhi V. (2007). Eco-industrial clusters in urban-rural fringe areas. A strategic approach for integrated environmental and economic planning business and the environment project institute for global environmental strategies - Kansai Research Centre

[2] Athayde R.(2009). Measuring enterprise potential in young people. ETP, Baylor University. March 2009

[3] Bennett, (2008). How San Diego biotech started and where It's going. Voice of San Diego. Monday, Aug. 4, 2008

[4] Bijaoui, I. (2012). From Necessity to Business Entrepreneurship: The Case of the Songhai Center, Porto Novo, Benin. African Journal of Business Management. Vol. 6(18), pp. 5872-5878

[5] Bijaoui I., Tarba, Y.S. (2012) Sub Saharan African (ASS) countries towards economic development: The process model African Journal of Business Management. Vol.5 (13), July, 2012

[6] Bonnet J., Le Pape, N., Nelson, T. (2011).Firm start-up strategies and performance in France: Survival and growth, in submission to JEMS (Journal of Economics and Management Strategy.

[7] 'Entrepreneuriat, éditeur Alain Fayolle, éditions EMS

[8] Caird, S. (1992). Problems with the Identification of Enterprise Competencies and the Implications for Assessment and Development. Management Education and Development 23 (1): 6-17.

[9] Cawthorne, P. (1995). Of Networks and Markets: The Rise and rise of a south Indian town. The example of Tiruppur's cotton knitting industry" World Development, 23 (1), 43-56

[10] C.B.S (2011). Annual Report 2011, Table 2-17

[11] Colovic-Lamotte, A., Tayanagi, E. (2004) "What direction should the cluster policy take, top down implementation or bottom up emergence. PhD University of Paris-Dauphine Research Center DMSP

[12] European Commission, (2007). Innovation Clusters in Europe: A statistical analysis and overview of current policy support. DG Enterprise and Industry report

[13] http://www.oecd.org/document/2/0,2340,en_2649_33735_38 174082_1_1_1_1,00.html/www.proinno-europe.eu/ www.clusterobservatory.eu

[14] E.U. (2012). Commission staff working document a view on employment, growth and innovation in rural areas. E.U. Commission Brussels, 7.3.2012SWD (2012) 44 final.

[15] Eurostat (2012). Urban-intermediate-rural regions Around 40\% of the EU27 population live in urban regions and almost a quarter in rural regions.

[16] Eurostat press office 51/2012 - 30 March 2012

[17] Fayolle, A., Gailly, B. (2009) . Evaluation d'une formation en entrepreneuriat :

[18] prédispositions et impacts sur l'intention d'entreprendre, Management, 12(3), 176-203.

[19] Giacomin, O., Janssen, F., Guyot, J.L., Lohest, O. (2011). Opportunity and/or necessity entrepreneurship? The impact of the socio-economic characteristics of entrepreneurs. MPRA Paper No. 29506, posted 10. March 2011 / 09:01

[20] Gilad, B., Levine, P. (1986). A behavioral model of entrepreneurial supply, Journal of Small Business Management, 24(4), 45-51.

[21] Gladwell, M. (2000). The Tipping Point, Little, Brown and Company, Boston, New York, London

[22] Keh, H. T., Nguyen, T. T. M., Ng, H.P., (2007). "The effects of entrepreneurial orientation and marketing information on the performance of SMEs", Journal of Business Venturing, 22, 592-611.

[23] Kim, N., Wicks, B.E. (2010). Rethinking tourism cluster development models for global competitiveness. University of Massachusetts - Amherst

[24] International CHRIE Conference-Refereed Track 2010 ICHRIE Conference Jul 30th,

[25] Kurilsky, M. L., Walstad, W. B. (2000). The “E” Generation: Prepared for the entrepreneurial economy? Kendall Hunt Publishing Company.

[26] McClelland, D.C. (1971). The achievement motive in economic growth.in P. Kilby (Ed.), Entrepreneurship and economic development (pp.108-122). New York: Free Press.

[27] Moreno, A. M., Casillas, J. C. (2008), "Entrepreneurial orientation and growth of SMEs: A causal model", Entrepreneurship Theory and Practice, 32, 507-528.

[28] Peña V., Transue M., Shipp S., Van Atta R. (2010). A Survey of entrepreneurship education initiatives. Science and Technology institute, Institute for Defense Analysis IDA Document NS D-4091 May 2010 
[29] Porter, M. E. (1990). The Competitive advantage of nations. New York: The Free Press, pp. 131- 238.

[30] Porter, M.E., (1998). Clusters and competition: New agendas for companies, governments, and institutions. In M.E. Porter (ed.). On competition. Harvard: Business School Press, pp. 197-299.

[31] Raines, P. (2002). The challenge of evaluating cluster behaviour in economic development policy. Paper presented to the International RSA Conference: Evaluation and EU regional policy: New questions and challenges.

[32] Schwab K. (2011) The global competitiveness Report 20112012, World Economic Forum, 2011, Geneva.

[33] Shane, S \& S. Venkataraman (2000) The promise of entrepreneurship as a field of research, Academy of Management Review, Vol. 25

[34] Stam E. (2008) "Entrepreneurship and innovation policy", Jena Economic Research Papers, 006, Friedrich-Schiller-Un iversity Jena, Max-Planck-Institute of Economics

[35] TEKES(2005). Annual Review. Finnish funding agency for technology and innovation(TEKES), Helsinki, Finland.
[36] Thurik, R.A. (2008). "Entrepreneurship, economic growth and policy in emerging economies", ERIM Paper ERS-2008-060-ORG, p.6.

[37] Verheul I., Van Stel, A. (2010), "Entrepreneurial diversity and economic growth", pp.17-36 in The Entrepreneurial society: how to fill the gap between knowledge and innovation, Edited by Jean Bonnet, Domingo García-Pérez-de-Lema, Howard Van Auken, 260 pages, Edward Elgar Publishing.

[38] Walukiewicz S. (2003). The role of clusters in setting up regional governance in Poland. $2^{\text {nd }}$ Workshop of the EU Thematic Network Project REGIONET "Regional Sustainable Development - Strategies for Effective Multi-Level Governance" 29-31 January 2003, Lillehammer, Norway

[39] Wennekers, S., and R. Thurik (1999). "Linking entrepreneurship and economic growth." Small Business Economics 13: 27-55.

[40] Wiklund, J., and D. Sheperd (2005). "Entrepreneurial orientation and small business performance: A Configurational Approach", Journal of Business Venturing, 20, 71-91. 